\title{
Cyclocondensation Reactions of Hydrazonoyl Chlorides with Some Azines: Synthesis of New Fused Heterocycles of Expected Microbiological Activity
}

\author{
Mosselhi A. M. Mohamed ${ }^{1,2 *}$, Liala M. B. Abu-Alola' ${ }^{1}$, Ohoud N. A. Al-Zaidi' ${ }^{3}$, Hosam A. H. Saad ${ }^{1,4}$ \\ ${ }^{1}$ Department of Chemistry, Faculty of Science, Taif University, Taif, Saudi Arabia \\ ${ }^{2}$ Department of Chemistry, Faculty of Science, Cairo University, Giza, Egypt \\ ${ }^{3}$ Department of Chemistry, College of Education \& Science, Taif University, Taif, Saudi Arabia \\ ${ }^{4}$ Department of Chemistry, Faculty of Science, Zagazig University, Zagazig, Egypt \\ Email: *mosselhimohamed@yahoo.com
}

How to cite this paper: Mohamed, M.A.M., Abu-Alola, L.M.B., Al-Zaidi, O.N.A. and Saad, H.A.H. (2017) Cyclocondensation Reactions of Hydrazonoyl Chlorides with Some Azines: Synthesis of New Fused Heterocycles of Expected Microbiological Activity. International Journal of Organic Chemistry, 7, 12-24.

https://doi.org/10.4236/ijoc.2017.71002

Received: October 21, 2016

Accepted: December 24, 2016

Published: December 27, 2016

Copyright $\odot 2017$ by authors and Scientific Research Publishing Inc. This work is licensed under the Creative Commons Attribution International License (CC BY 4.0).

http://creativecommons.org/licenses/by/4.0/

\begin{abstract}
New functionalized fused heterocycles, such as, 1,3,6,9,11-pentasubstituted-pyrido[3,2-f:6,5- $f]$ bis $([1,2,4]$ triazolo $[4,3-a]$-pyrimidin-5(1H)-ones $(6)$ and 1,3-disubstituted-7-[(E)-2-(thiophen-2-yl)ethenyl]-1,4,9,9a-tetrahydro-6H-[1,2,4] triazino[4,3-b][1,2,4,5]-tetrazin-6-ones (16) were synthesized via reaction of the hydrazonoyl chlorides (1) with 1,3,6-triphenyl-9-thioxo-9,10-dihydro-pyrimido $[4,5-b]$ pyrido $[4,5-d][1,2,4]$ triazolo $[4,3-a]$ pyrimidin-5,7 $(1 H, 8 H)$-di-one (5) and 4-amino-6-[(2-thiophen-2-yl)ethenyl]-3-thioxo-3,4-dihydro-[1,2,4]triazin-5(2H)-one (11), respectively. The mechanism and the regioselectivity of the studied reactions have been discussed. The biological activity of the products has been evaluated against some fungi and bacteria species. The tested compounds exhibited moderate activity against the bacteria species.
\end{abstract}

\section{Keywords}

Hydrazonoyl Chlorides, Azines, Fused Heterocycles, Biological Activity

\section{Introduction}

The interest in the chemistry of hydrazonoyl halides is a consequence of the fact that they undergo a wide variety of reactions which provide routes to a number of both heterocyclic and acyclic compounds [1] [2] [3] [4]. In addition, diverse biological activities such as anthelmintic, antiviral, antimicrobial, pesticidal, etc., have been found to be associated with hydrazonoyl halides. In recent years, interest to the chemistry of this class of compounds has been renewed because of 
the development of novel synthetic routes and their use as versatile synthon in synthesis of other compounds that found many applications in both industrial and pharmaceutical fields [5]-[19]. In continuation of our studies dealing with the utility of hydrazonoyl halides for synthesis of various heterocycles [3] [16] [20] [21] [22], we wish to report herein a new facile synthesis of 1,3,6,9,11-pentasubstituted pyrido[3,2-f:6,5- $f]$ bis([1,2,4]triazolo[4,3-a]-pyrimidin-5(1H)-ones (6) and 1,3-disubstituted-7-[(E)-2-(thiophen-2-yl)ethenyl]-1,4,9,9a-tetrahydro$6 H$-[1,2,4] triazino[4,3-b] $[1,2,4,5]$-tetrazin-6-ones (16) that have not been reported hitherto, via cyclocondensation reactions of hydrazonoyl chlorides with some azines. Our interest in exploring a new simple synthetic strategy for the latter ring system is due to the fact that literature search reveals that the design and synthesis of novel mono-, di-, and poly-cyclic fused nitrogen heterocyclic compounds are among the active principles in chemical materials, particularly those displaying strategic roles in the development of different industries, especially from the biological point of view. Development of heterocycles with antimicrobial and antitumor activities represents one of the most important researches in therapeutical chemistry [23].

Some fused heterocycles showed antibacterial, antifungal [24], antiphlogistic, antitumor [25], herbicidal [26] and in vitro antiviral and antitumor activities [27].

\section{Material and Methods}

\subsection{Chemistry}

All melting points were measured on an electrothermal melting point apparatus and are uncorrected. The ${ }^{1} \mathrm{H}$ and ${ }^{13} \mathrm{C}$ NMR spectra were recorded in deuterated dimethyl sulphoxide (DMSO- $d_{\sigma}$ ) at $300 \mathrm{MHz}$ on a Varian Mercury VXR-300 NMR spectrometer (Cairo University, Egypt). $600 \mathrm{MHz}$ Bruker NMR spectrometer (King Abdelaziz University, Saudi Arabia) and chemical shifts were related to that of the solvent. The infrared spectra were recorded in potassium bromide discs on a Pye-Unicam, SP300 and Shimadzu, FT IR 8101 PC infrared spectrophotometers.

Biological activity was carried out at the Microanalytical Center of Cairo University, Cairo, Egypt. Mass spectra were recorded on a Shimadzu GC MS-QP 1000 EX mass spectrometer at $70 \mathrm{e.V}$. Elemental analyses were carried out at the Microanalytical Center of Cairo University, Cairo, Egypt. The starting compounds, $\mathrm{N}$-phenyl benzenecarbohydrazonoylchloride (1a) [28] [29] [30], $N$-phenyl-2-phenylami-no-2oxoethanehydrazonoyl chloride (1b), $N$-phenyl-2-oxopropanehydrazonoyl chloride (1c), ethyl $N$-phenylhydrazonochloroacetate (1d) and ethyl $N$-p-nitro-phenylhydrazonochloroacetate (1e) [20] [31] were prepared as previously reported.

Reaction of $N$-Phenyl benzenecarbohydrazonoyl chloride (1a) with 6aminouracil-2-thione (2): Synthesis of 7-amino-1,3-diphenyl [1,2,4]triazolo [4,3-a]pyrimidin-5(1H)-one (3) [21].

To a mixture of 6-aminouracil-2-thione (2) [32] (2.8 g, $20 \mathrm{mmol})$ and $\mathrm{N}$ phenyl benzenecarbohydrazonoyl chloride (1a) (4.6 g, $20 \mathrm{mmol})$ in $50 \mathrm{ml}$ dio- 
xane (and $10 \mathrm{ml}$ DMF for solubility reasons), $2.8 \mathrm{ml}(20 \mathrm{mmol})$ of triethylamine were added, and the mixture was heated under reflux until $\mathrm{H}_{2} \mathrm{~S}$ evolution ceased (15h).Then the solvent was distilled off, and the residue was cooled. The solid formed was filtered, washed with methanol and crystallized from ethanol : dioxane $(\mathrm{v} / \mathrm{v}, 3: 1)$ to give 7-amino-1,3-diphenyl[1,2,4]triazolo[4,3-a] pyrimidin5(1H)-one (3), yield: 2.29 g (38.6\%); m.p. $260^{\circ} \mathrm{C}-262^{\circ} \mathrm{C}$ (Lit. m.p. $262^{\circ} \mathrm{C}-$ $\left.264^{\circ} \mathrm{C}[21]\right)$.

Reaction of 7-Amino-1,3-diphenyl[1,2,4]triazolo[4,3-a]pyrimidin-5(1H)one (3) with benzaldehyde and ethyl cyanoacetate: Synthesis of 8-amino1,3,6-triphenyl-7-ethoxycarbonyl-pyrido[2,3- $f[1,2,4]$ triazolo[4,3-a]pyrimid in-5 $(1 H)$-one $(4)$.

7-Amino-1,3-diphenyl[1,2,4]triazolo[4,3-a]pyrimidin-5(1H)-one (3) (2 g, 6.6 mmol) was dissolved in $40 \mathrm{ml}$ of dimethylformamide. To this solution, $0.8 \mathrm{ml}$ ( $6.6 \mathrm{mmol})$ benzaldehyde and then $0.8 \mathrm{ml}(6.6 \mathrm{mmol})$ ethyl cyanoacetate were added. The mixture was refluxed for $6 \mathrm{~h}$. After cooling, the solvent was evaporated and $20 \mathrm{ml} \mathrm{H}_{2} \mathrm{O}$ cold was added. The solid formed was filtered, washed with cold $\mathrm{H}_{2} \mathrm{O}$ and then crystallized from ethanol:dioxane $(\mathrm{v} / \mathrm{v}, 9: 1)$ to give 4 .

Yield: $3.3 \mathrm{~g}(99.69 \%)$; m.p. $297^{\circ} \mathrm{C}-300^{\circ} \mathrm{C}$; IR $(\mathrm{KBr}): \bar{V}=3348,3164\left(\mathrm{NH}_{2}\right)$, 1671, $1634(\mathrm{CO}) \mathrm{cm}^{-1} ;{ }^{1} \mathrm{H}$ NMR $\left(\mathrm{CDCl}_{3}\right): \delta, 1.25\left(\mathrm{t}, 3 \mathrm{H}, \mathrm{CH}_{3}\right), 4.31(\mathrm{q}, J=7.3,2 \mathrm{H}$, $\mathrm{CH}_{2}$ ), 6.75 (s, 2H. $\mathrm{NH}_{2}, \mathrm{D}_{2} \mathrm{O}$ exchangeable), $7.20-7.80(\mathrm{~m}, 15 \mathrm{H}, \mathrm{Ar}-\mathrm{H}) ;{ }^{13} \mathrm{C}$ NMR (DMSO- $\left.d_{6}, 75 \mathrm{MHz}\right): \delta, 14.0\left(\mathrm{CH}_{3}\right), 60.5\left(\mathrm{CH}_{2}\right), 107.0,108.0$, [Ar-C, 120.8, 122 - 129.63, 130.67, 131.01, 131.68, 137.47], 145.17, 152.0, 153.0, 154.0, 155.5, 158.3, 161.0, 163.5 (CO), 166.0 (CO); EIMS (m/z,\%) $502\left(\mathrm{M}^{+}, 20\right)$. Anal. calcd. for $\mathrm{C}_{29} \mathrm{H}_{22} \mathrm{~N}_{6} \mathrm{O}_{3}$ (502.5); C, 69.31; H, 4.41; N, 16.72. Found: C, 69.24; H, 4.44; N, $16.49 \%$.

Reaction of 4 with potassium thiocyanate: Synthesis of 1,3,6-triphenyl-9-thioxo-9,10-dihydropyrimido[4,5-b]pyrido[4,5- $d][1,2,4]$ triazolo[4,3a]pyrimidin-5,7(1H,8H)-dione (5).

To a solution of $4(1 \mathrm{~g}, 1.99 \mathrm{mmol})$ and dioxane in acetic acid $(20 \mathrm{ml})$ and drops $10 \% \mathrm{HCl}$, potassium thiocyanate $(0.1 \mathrm{~g}, 1.03 \mathrm{mmol})$ was added and the mixture was refluxed for $7 \mathrm{~h}$. After cooling, the solvent was evaporated and 20 $\mathrm{ml} \mathrm{H}_{2} \mathrm{O}$ was added. The solid formed was filtered, washed with $\mathrm{H}_{2} \mathrm{O}$ and crystallized from ethanol and drops of dioxane to give $\mathbf{5}$ as pale yellow crystals.

Yield: 0.9 g (87.73\%); m.p. $270^{\circ} \mathrm{C}$; IR $(\mathrm{KBr}): \bar{V}=3277,3074(2 \mathrm{NH}), 1672$, $1630(\mathrm{CO}) \mathrm{cm}^{-1}$; ${ }^{1} \mathrm{H}$ NMR (DMSO- $\left.d_{\sigma}\right): \delta, 7.10-8.25(\mathrm{~m}, 15 \mathrm{H}, \mathrm{Ar}-\mathrm{H}), 9.45(\mathrm{~s}$, $1 \mathrm{H}, \mathrm{NH}), 11.19(\mathrm{~s}, 1 \mathrm{H}, \mathrm{NH}) ;{ }^{13} \mathrm{C}$ NMR (DMSO- $\left.d_{6}, 75 \mathrm{MHz}\right): \delta, 119.8,113.0$, 116.0, [Ar-C, 122 - 129.53, 130.0, 131.0, 132.8, 137.5], 140.99, 143.46, 146.46, 154.32, 155.45, 156.0, 161.8, 167.46; EIMS $(\mathrm{m} / \mathrm{z}, \%) 515\left(\mathrm{M}^{+}, 10\right)$. Anal. calcd. for $\mathrm{C}_{28} \mathrm{H}_{17} \mathrm{~N}_{7} \mathrm{O}_{2} \mathrm{~S}$ (515.55); C, 65.23; H, 3.32; N, 19.02; S,6.22. Found: C, 65.00; H, 3.30; N, 18.70; S, 6.15\%.

Reaction of 5 with hydrazonoyl chlorides, ( $N$-phenyl benzenecarbohydrazonoyl chloride(1a) \& $N$-Phenyl-2-Phenylamino-2-oxoethanehydrazonoyl chloride (1b)): Synthesis of 1,3,6,9,11-pentasubstituted-pyrido[3,2f.6,5- $f]$ bis ([1,2,4]triazolo[4,3-a]-pyrimidin-5(1H)-ones (6). 
Toa mixture of 1,3,6-triphenyl-9-thioxo-9,10-dihydropyrimido[4,5- $b$ ]pyrido [4,5-d][1,2,4]triazolo[4,3-a]pyrimidine-5,7(1H,8H)-dione (5) (0.5 g, $1 \mathrm{mmol})$ and the appropriate hydrazonoyl chloride $1 \mathrm{a}$ or $1 \mathrm{~b}(1 \mathrm{mmol})$ in $15 \mathrm{ml}$ dioxane and triethylamine $(0.15 \mathrm{ml}, 1 \mathrm{mmol})$ were added. The reaction mixture was heated under reflux until the evolution of hydrogen sulfide gas had ceased, for (24 h) (as evidenced by TLC). The reaction mixture, on cooling, afforded only one product in each case (TLC) and then the solvent was distilled off, and the residue was cooled. The solid formed was filtered, washed with $\mathrm{H}_{2} \mathrm{O}$, and crystallized from ethanol: dioxane ( $\mathrm{v} / \mathrm{v}, 9: 1)$ to give 6 .

1,3,6,9,11-pentaphenylpyrido[3,2-f:6,5- $f]$ bis([1,2,4] triazolo[4,3-a]-pyrimi din-5(1H)-ones (6a).

Yield: 0.2 g (30.52\%);Yellow crystals; m.p. $294^{\circ} \mathrm{C}$; IR (KBr): $\bar{V}=1671,1636$ (CO) $\mathrm{cm}^{-1} ;{ }^{1} \mathrm{H}$ NMR (DMSO- $d_{6}$ ): $\delta, 7.06-8.26(\mathrm{~m}, 25 \mathrm{H}, \mathrm{Ar}-\mathrm{H}) ;{ }^{13} \mathrm{C}$ NMR (DMSO- $\left.d_{6}, 75 \mathrm{MHz}\right): \delta,[\mathrm{Ar}-\mathrm{C}, 122-129.53,130.0,131.0,132.8,137.5,139.0]$, $141.5,142.0,144.5,148.8,152.0,154.2,155.5,159.0,163.0$; EIMS $(\mathrm{m} / z, \%) 676$ $\left(\mathrm{M}^{+}+1\right.$, 35). Anal. calcd. for $\mathrm{C}_{41} \mathrm{H}_{25} \mathrm{~N}_{9} \mathrm{O}_{2}(675.7) ; \mathrm{C}, 72.88 ; \mathrm{H}, 3.73 ; \mathrm{N}, 18.66$. Found: C, 72.50; H, 3.80; N, 18.50\%.

1,3,6,11-tetraphenyl-9-phenylaminocarbonylpyrido[3,2-f.6,5- $f] \mathrm{di}([1,2,4]$ triazolo[4,3-a]-pyrimidin-5(1H)-ones (6b).

Yield: $0.2 \mathrm{~g}$ (28.69\%); Yellow solid; m.p. $272^{\circ} \mathrm{C}-273^{\circ} \mathrm{C}$; IR (KBr): $\bar{V}=3433$ $(\mathrm{NH}), 1684,1605(\mathrm{CO}) \mathrm{cm}^{-1} ;{ }^{1} \mathrm{H}$ NMR (DMSO- $\left.d_{\sigma}\right): \delta, 7.17-8.23(\mathrm{~m}, 25 \mathrm{H}$, Ar-H), 10.77 (s, $1 \mathrm{H}, \mathrm{NH}$ ); ${ }^{13} \mathrm{C}$ NMR (DMSO- $d_{6}, 75 \mathrm{MHz}$ ): $\delta$, [Ar-C, 122 - 129.5, $130.5,131.8,132.9,137.5,139.2], 141.0,142.2,144.3,148.5,151.3,152.5,154.2$, 155.5, 158.5, 164.0; EIMS $(\mathrm{m} / z, \%) 718\left(\mathrm{M}^{+}, 25\right)$. Anal. calcd. for $\mathrm{C}_{42} \mathrm{H}_{26} \mathrm{~N}_{10} \mathrm{O}_{3}$ (718.72); C, 70.19; H, 3.65; N, 19.49. Found: C, 70.0; H, 3.50; N, 19.30\%.

Reaction of hydrazonoyl chlorides (1a-d) with 4-amino-6-[(2-thiophen-2yl)ethenyl]-3-thioxo-3,4-dihydro-[1,2,4]triazin-5(2H)-one (11).

General procedure:

To a mixture of 4-amino-6-[(2-thiophen-2-yl)ethenyl]-3-thioxo-3,4-dihydro$[1,2,4]$ triazin-5(2H)-one (11) (2 mmol) [33] and an appropriate hydrazonoyl chlorides (1a-d) $(1 \mathrm{mmol})$ in chloroform $(20 \mathrm{ml})$ was added triethylamine $(0.4$ $\mathrm{ml}, 2.5 \mathrm{mmol}$ ) and the reaction mixture was stirred at room temperature for (15 - $24 \mathrm{~h}$ ). The solid that precipitated was filtered off, washed with water, dried and finally crystallized from ethanol to give chromatographically, impure products, which were purified by column chromatography $\left(\mathrm{EA} / \mathrm{CHCl}_{3}, 10: 90\right)$ to give pure yellow crystals (16a-d).

16a: 1,3-diphenyl-7-[(E)-2-(thiophen-2-yl)ethenyl]-1,4,9,9a-tetrahydro$6 H$-[1,2,4] triazino[4,3-b][1,2,4,5]tetrazin-6-one.

Yield: 0.2 g, 24.39\%; yellow solid; m.p. $174^{\circ} \mathrm{C}$; IR $(\mathrm{KBr}) \quad \bar{V}, \mathrm{~cm}^{-1}=3432,3269$ $(2 \mathrm{NH}), 1657(\mathrm{CO}) ;{ }^{1} \mathrm{H}$ NMR $\left(\mathrm{CDCl}_{3}\right): \delta 7.0-8.2(\mathrm{~m}, 15 \mathrm{H}, \mathrm{Ar}-\mathrm{H} \& \mathrm{CH}=\mathrm{CH}$, thienyl-3H), $8.8(\mathrm{~s}, 1 \mathrm{H}, \mathrm{NH}) ;{ }^{13} \mathrm{C}$ NMR $\delta: 119.4,123.68,125.93,126.8,127.0$, $127.63,127.99,128.9,129.16,129.28,129.8,132.12,139.66,141.37,142.15,146.6$, 147.0, 149.99, 164.0. MS, $\mathrm{m} / z$ (\%): $412\left(\mathrm{M}^{+}, 25\right)$. Anal. Calcd. for $\mathrm{C}_{22} \mathrm{H}_{16} \mathrm{~N}_{6} \mathrm{OS}$ (412.47): C, 64.06; H, 3.91; N, 20.38; S, 7.77. Found: C, 63.92; H, 4.05; N, 20.10; S, 
$7.60 \%$.

16b: 3-Phenylamido-1-phenyl-7-[(E)-2-(thiophen-2-yl)ethenyl]-1,4,9,9atetrahydro- $6 H-[1,2,4]$ triazino $[4,3-b][1,2,4,5]$ tetrazin-6-one.

Yield: 0.2 g, 22. $15 \%$; yellow solid; m.p. $211^{\circ} \mathrm{C}-214^{\circ} \mathrm{C}$; IR $(\mathrm{KBr}) \bar{V}, \mathrm{~cm}^{-1}=$ 3381, $3160(2 \mathrm{NH}), 1645,1600$ (2CO); ${ }^{1} \mathrm{H}$ NMR (DMSO- $\left.d_{6}\right): \delta 7.01-7.76(\mathrm{~m}, 15$ $\mathrm{H}, \mathrm{Ar}-\mathrm{H} \& \mathrm{CH}=\mathrm{CH}$, thienyl-3H), $10.18(\mathrm{~s}, 1 \mathrm{H}, \mathrm{NH}), 11.7$ (s, $1 \mathrm{H}, \mathrm{NH}) ;{ }^{13} \mathrm{C} \mathrm{NMR}$ $\delta: 114.67,115.85,120.28,120.97,122.78,122.98,124.16,127.28,128.67,129.35$, 129.59, 138.29, 142.19, 163.0, 168.0 . MS, $m / z(\%): 455\left(\mathrm{M}^{+}, 28\right)$. Anal. Calcd. for $\mathrm{C}_{23} \mathrm{H}_{17} \mathrm{~N}_{7} \mathrm{O}_{2} \mathrm{~S}$ (455.49); C, 60.65; H, 3.76; N, 21.53; S, 7.04. Found: C, 60.22; H, $3.50 ; \mathrm{N}, 21.40 ; \mathrm{S}, 7.00 \%$.

16c: 3-Acetyl-1-phenyl-7-[(E)-2-(thiophen-2-yl)ethenyl]-1,4,9,9a-tetrahydro-6 $H$ - $[1,2,4]$ triazino $[4,3-b][1,2,4,5]$ tetrazin-6-one.

Yield: $0.1 \mathrm{~g}, 13.33 \%$; pale yellow solid; m.p. $105^{\circ} \mathrm{C}$; IR (KBr) $\bar{V}, \mathrm{~cm}^{-1}=3350$, $3190(2 \mathrm{NH}), 1700,1630$ (2CO); ${ }^{1} \mathrm{H}$ NMR (DMSO- $\left.d_{6}\right): \delta 2.49\left(\mathrm{~s}, 3 \mathrm{H}, \mathrm{CH}_{3}\right), 6.9-$ $8.08\left(\mathrm{~m}, 10 \mathrm{H}, \mathrm{Ar}-\mathrm{H} \& \mathrm{CH}=\mathrm{CH}\right.$, thienyl-3H), $8.9(\mathrm{~s}, 1 \mathrm{H}, \mathrm{NH}) ;{ }^{13} \mathrm{C}$ NMR $\delta: 24.1$ $\left(\mathrm{CH}_{3}\right), 116.2,119.38,124.13,126.98,128.05,128.55,128.82,129.19,140.05$, 143.09,162.0, 168 . MS, $\mathrm{m} / z(\%): 378\left(\mathrm{M}^{+}, 43\right)$. Anal. Calcd. for $\mathrm{C}_{18} \mathrm{H}_{14} \mathrm{~N}_{6} \mathrm{O}_{2} \mathrm{~S}$ (378.41), C, 57.13; H, 3.73; N, 22.21; S, 8.47. Found: C, 56.86; H, 4.00; N, 21.90; S, $8.30 \%$.

16d: Ethyloxo-1-phenyl-7-[(E)-2-(thiophen-2-yl)ethenyl]-1,6,9,9a-tetrahydro-4H-[1,2,4] triazino[4,3-b][1,2,4,5] tetrazin-3-carboxylate.

Yield: 0.2 g, 24.69\%; orange solid; m.p. $1118^{\circ} \mathrm{C}$; IR $(\mathrm{KBr}) \bar{V}, \mathrm{~cm}^{-1}=3431$, $3000(2 \mathrm{NH}), 1737,1676(2 \mathrm{CO}) ;{ }^{1} \mathrm{H}$ NMR (DMSO- $\left.d_{6}\right): \delta 1.2\left(\mathrm{t}, 3 \mathrm{H}, \mathrm{CH}_{3}\right), 4.18(\mathrm{q}$, $\left.J=7.3,2 \mathrm{H}, \mathrm{CH}_{2}\right), 6.99-7.37(\mathrm{~m}, 10 \mathrm{H}, \mathrm{Ar}-\mathrm{H} \& \mathrm{CH}=\mathrm{CH}$, thienyl-3H), $10.79(\mathrm{~s}$, $1 \mathrm{H}, \mathrm{NH}) ;{ }^{13} \mathrm{C}$ NMR $\delta: 14.0\left(\mathrm{CH}_{3}\right), 61.5\left(\mathrm{CH}_{2}\right), 114.5,116.9,119.38,122.65$, $126.98,128.05,129.3,140.05,142.63,162.5,169.5$. MS, $\mathrm{m} / z(\%): 408\left(\mathrm{M}^{+}, 38\right)$. Anal. Calcd. for $\mathrm{C}_{19} \mathrm{H}_{16} \mathrm{~N}_{6} \mathrm{O}_{3} \mathrm{~S}$ (408.43); C, 55.87; H, 3.95; N, 20.58; S, 7.85. Found: C, 55.60; H, 4.20; N, 20.40; S, 8.00\%.

\subsection{Antimicrobial Assay}

Cultures of two bacterial species namely, Escherichia coli EC, and Staphylococcus aureus $\mathrm{SA}$ as well as well as two fungal species, namely Aspergillus flavus AF, and Candida albicans CA were used to investigate the antimicrobial activity of eight products, namely $4,5,6 \mathrm{a}, 6 \mathrm{~b}$ and $16 \mathrm{a}-16 \mathrm{~d}$. The antimicrobial activity tests were carried out in the Microbiology Division of Microanalytical Center of Cairo university using the diffusion plate technique [34] [35]. The latter technique was carried out by pouring a spore suspension of the fungal species $\left(1 \mathrm{~cm}^{3}\right.$ of sterile water contains approximately 108 conidia) or spreading bacterial suspension over a solidified malt agar medium. The layer is allowed to set for $30 \mathrm{~min}$. A solution of the test compounds $\left(1.0 \mathrm{~g}=\mathrm{cm}^{3}\right)$ in DMSO was placed onto sterile $5 \mathrm{~mm}$ filter paper discs and allowed to dry, then the discs were placed on the centre of the malt agar plate and incubated at optimum incubation temperature $28^{\circ} \mathrm{C} \pm 2^{\circ} \mathrm{C}$. The bactericide Ampicillinand, the fungicide Amphotericin B were used as standards under the same conditions. Measurements were considered after $72 \mathrm{~h}$ for 
fungi and $24 \mathrm{~h}$ for bacteria. The results are summarized in table.

\section{Results and Discussion}

\subsection{Chemistry}

The first required starting material in this part, 7-amino-1,3-diphenyl[1,2,4] triazolo[4,3-a]pyrimidin-5(1H)-one (3) [21] was prepared by reaction of the hydrazonoyl chloride 1a with 6-aminouracil-2-thione (2) [32] in dioxane and triethyamine. Reaction of the compound 3 with benzaldehyde and ethyl cyanoacetate in dimethylformamide afforded the corresponding 8-amino-7-ethoxycarbonyl-1,3,6-triphenylpyrido[2,3- $d]$ [1,2,4] triazolo[4,3-a]pyrimidin-5(1H)-one (4). The latter compound was cyclized by refluxing in a mixture of potassium thiocyanate and dioxane in the presence of concentrated hydrochloric acid affording1,3,6-triphenyl-9-thioxo-9,10-dihydropyrimido[4,5-b]-pyrido[4,5- $d][1,2$, 4] triazolo[4,3-a]pyrimidin-5,7(1H,8H)-dione (5) (Scheme 1).

The ${ }^{1} \mathrm{H}$ NMR spectrum of each of the resulting products 4 and 5 is in agreement with the given structure [see experimental part]. Hence, the product 4 revealed characteristic signals for ethyl ester and amino groups at $\delta=1.25(\mathrm{t}, 3 \mathrm{H}$, $\mathrm{CH}_{3}$ ), 4.31 (q, $J=7.3,2 \mathrm{H}, \mathrm{CH}_{2}$ ), 6.75 (s, 2H. $\mathrm{NH}_{2}, \mathrm{D}_{2} \mathrm{O}$ exchangeable), while the product 5 revealed characteristic signals of new $2 \mathrm{NH}$ at $\delta=9.45(\mathrm{~s}, 1 \mathrm{H}, \mathrm{NH}$, $\mathrm{D}_{2} \mathrm{O}$ exchangeable) and $11.19\left(\mathrm{~s}, 1 \mathrm{H}, \mathrm{NH}, \mathrm{D}_{2} \mathrm{O}\right.$ exchangeable). Reaction of

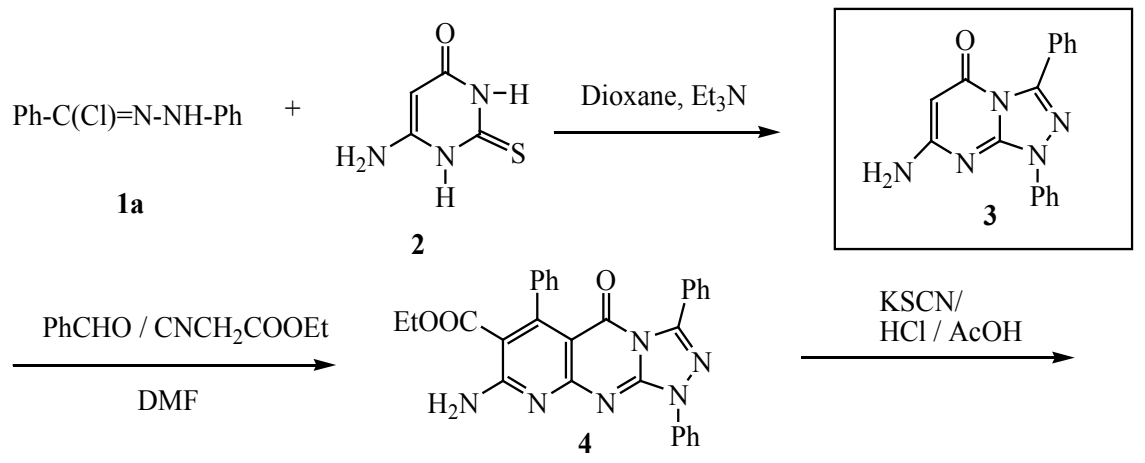<smiles></smiles>

$\mathrm{R}-\mathrm{C}(\mathrm{Cl})=\mathrm{N}-\mathrm{NH}-\mathrm{Ph}$

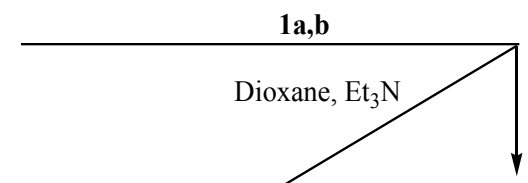<smiles>[R]c1nn(-c2ccccc2)c2nc3nc4c(=O)n(-c5ccccc5)c(-c5ccccc5)nn4c3c(=O)c-2c1[2H]</smiles><smiles></smiles>

$1,6,7: \mathrm{R}=\mathrm{Ph}(\mathrm{a}), \mathrm{CONHPh}(\mathrm{b})$

Scheme 1. Reaction of hydrazonoyl chloride with 1,3,6-triphenyl-9,10-dihydropyrimido $[4,5-b]$ pyrido $[4,5-d][1,2,4]$ triazolo[4,3-a]pyrimidin-5,7[1 $H, 18 i H]$-dione(5). 
1,3,6-triphenyl-9-thioxo-9,10-dihydropyrimido[4,5-b]pyrido[4,5- $d][1,2,4]$ triazolo[ 4,3-a]pyrimi-din-5,7(1H,8H)-dione (5) with hydrazonoyl chlorides 1a,b were carried out in dioxane in the presence of triethylamine at reflux until the evolution of hydrogen sulfide gas had ceased. The reaction mixture, on cooling, afforded only one product in each case (as evidenced by TLC). Both spectroscopic data and elemental analyses were consistent with structure 6 or 7 (Scheme 1). An immediate distinction between these two structures was reached by comparison of the ${ }^{13} \mathrm{C}$ NMR spectra with those of similar annulated pyrimidinones. Literature report [36] has shown that the chemical shift for the carbonyl carbon in 4-pyrimidi- none derivatives is markedly affected by the nature of the adjacent nitrogen (N8) (pyrrole type in structure 6 and pyridine type as in structure 7). For example, the ${ }^{13} \mathrm{C}$ NMR spectra of 6a taken as typical example of the series prepared, revealed the signals of the carbonyl carbon of the pyrimidinone ring residue at $\delta=163.15$. Such chemical shift values are similar to those of annulated pyrimidines with N8 pyrrole type rather than those of N8 pyridine type (Chart 1).

The chemical shift values of the annelatedpyrimidinones A and B are shown in Chart 1 [21] [22]. Since the values found for the isolated products are similar to those of A and not B, the products were assigned structure 6 .

On the basis of this similarity, the isolated products were assigned structure 6 and the isomeric structure 7 was excluded. As depicted in Scheme 1. The reaction proceeded through S-alkylation [37] to give $S$-alkylated products $\mathbf{8}$ followed by Smiles rearrangement [38], afforded intermediate 9 which consumed insitu via elimination of hydrogen sulfide gas to give the desired products $\mathbf{6} \mathbf{a}, \mathbf{b}$ (Scheme 2). The assignment for the structure products and reaction mechanism can be manifested by alternate synthesis. Thus, refluxing of 7-amino-1,3-diphenyl $[1,2,4]$ triazolo[4,3-a]pyrimidin-5(1H)-one (3) with benzaldehyde in acetic acid afforded directly the product $\mathbf{6 a}$ (Scheme 3 ) [22].

Also the reaction of 6-aminouracil-2-thione (2) with benzaldehyde in acetic acid afforded the compound 10 [39], which reacted with hydrazonoyl chloride (1a) to yield the product $6 \mathbf{a}$ [22] (Scheme 3 ). The product $\mathbf{6 a}$ obtained by the alternate synthesis found to be identical in all respects ( $\mathrm{mp}$, mixed $\mathrm{mp}$, IR and ${ }^{1} \mathrm{HNMR}$ ) with the product produced from the reaction of 5 with 1a in Scheme 1.

Our study was extended to introduce 1,2,4-triazine containing thiophene moiety which has wide applications in different biological and medicinal fields beside its application in organic chemistry [40] [41] [42] [43]. Thus hydrazonoyl chlorides (1a-d) reacted with 4-amino-6-[(2-thiophen-2-yl)ethenyl]-3-thioxo-

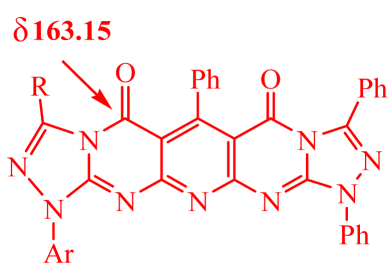

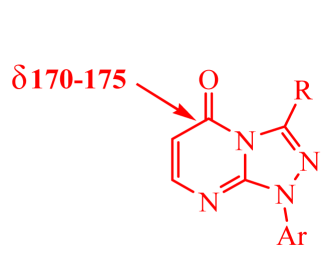

A $\delta 161-164$

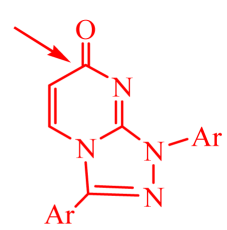

B

Chart $1 .{ }^{13} \mathrm{C}$ NMR Shifts of strategic carbon atoms. 


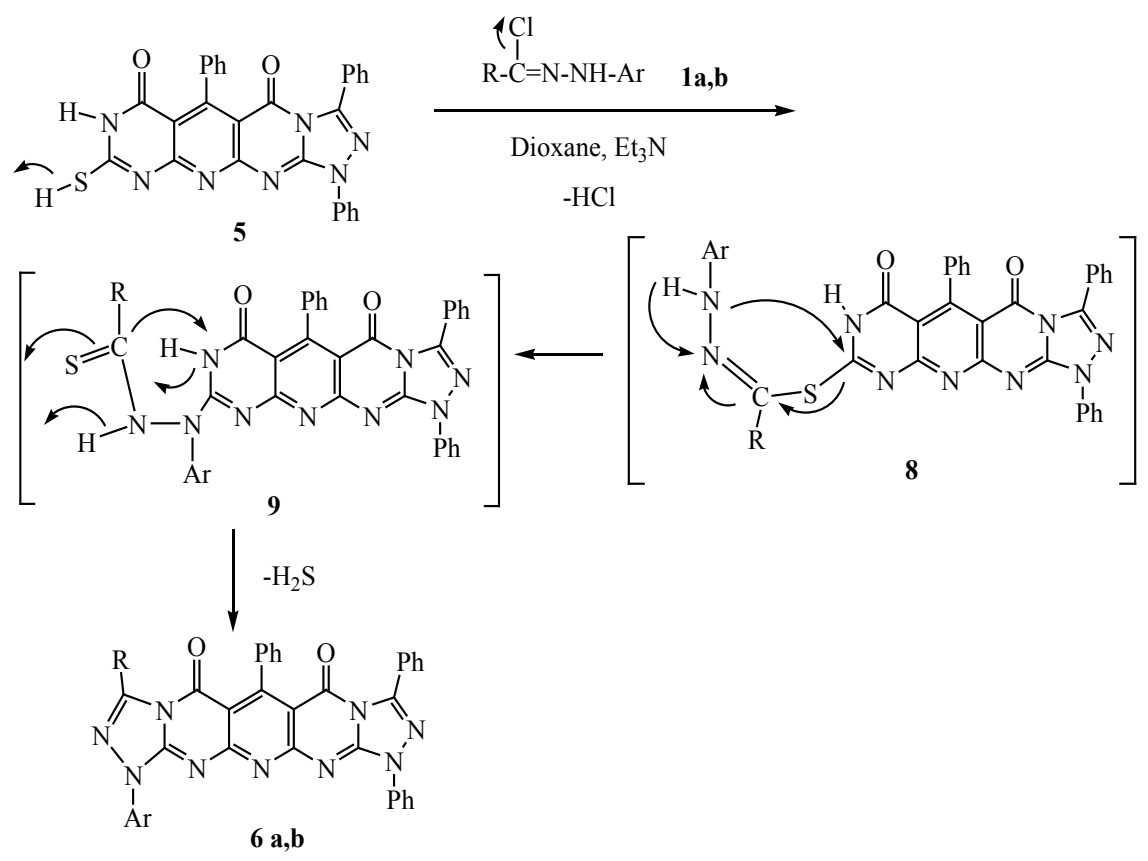

Scheme 2. Mechanism of the formation of 1,3,6,9,11,-pentasubstitited-pyrido [3,2-f:6,5- $f$ ] $\operatorname{di}([1,2,4])$ trizaolo[4,3-a]pyrimidin-5(1H)-one (6).<smiles>Nc1cc(=O)n2c(-c3ccccc3)nn(-c3ccccc3)c2n1</smiles><smiles>O=c1c2c(-c3ccccc3)c(=O)n3c(-c4ccccc4)nn(-c4ccccc4)c3nc-2nc2c1n(-c1ccccc1)n2-c1ccccc1</smiles>

6 a<smiles>Nc1cc(=O)[nH]c(=S)[nH]1</smiles>

2<smiles>O=c1[nH]c(=S)[nH]c2nc3[nH]c(=S)[nH]c(=O)c3c(-c3ccccc3)c12</smiles>

10

Scheme 3. Alternate Synthesis of 1,3,6,9,11-pentasubstituted-pyrido [3,2-f:6,5-f]di $([1,2,4])$ trizaolo[4,3-a]pyrimidin-5(1H)-one (6).

3,4- dihydro-[1,2,4]triazin-5(2H)-one (11) [40] in chloroform and triethylamine at room temperature for 15 - $24 \mathrm{~h}$ (according to TLC, no start was found) to give chromatographically impure product. The latter was purified by column chromatography by using eluent of a mixture of ethyl acetate $/ \mathrm{CHCl}_{3}$ (10:90) to give one single pure product. The structure of the product obtained may be 13 or 16 (Scheme 4).

It was initially anticipated that such reactions would yield the respective $1,2,4$ triazino[2,1- $b][1,3,4,5]$ thiatriazine (13) by analogy to the reactions of $1 \mathbf{a}-\mathbf{d}$ with 2-aminothiophenol, which were reported to afford benzothiadiazine derivatives [22] [39]. Unexpectedly, the products isolated from the reactions of $\mathbf{1 a - d}$ with $\mathbf{1 1}$ 


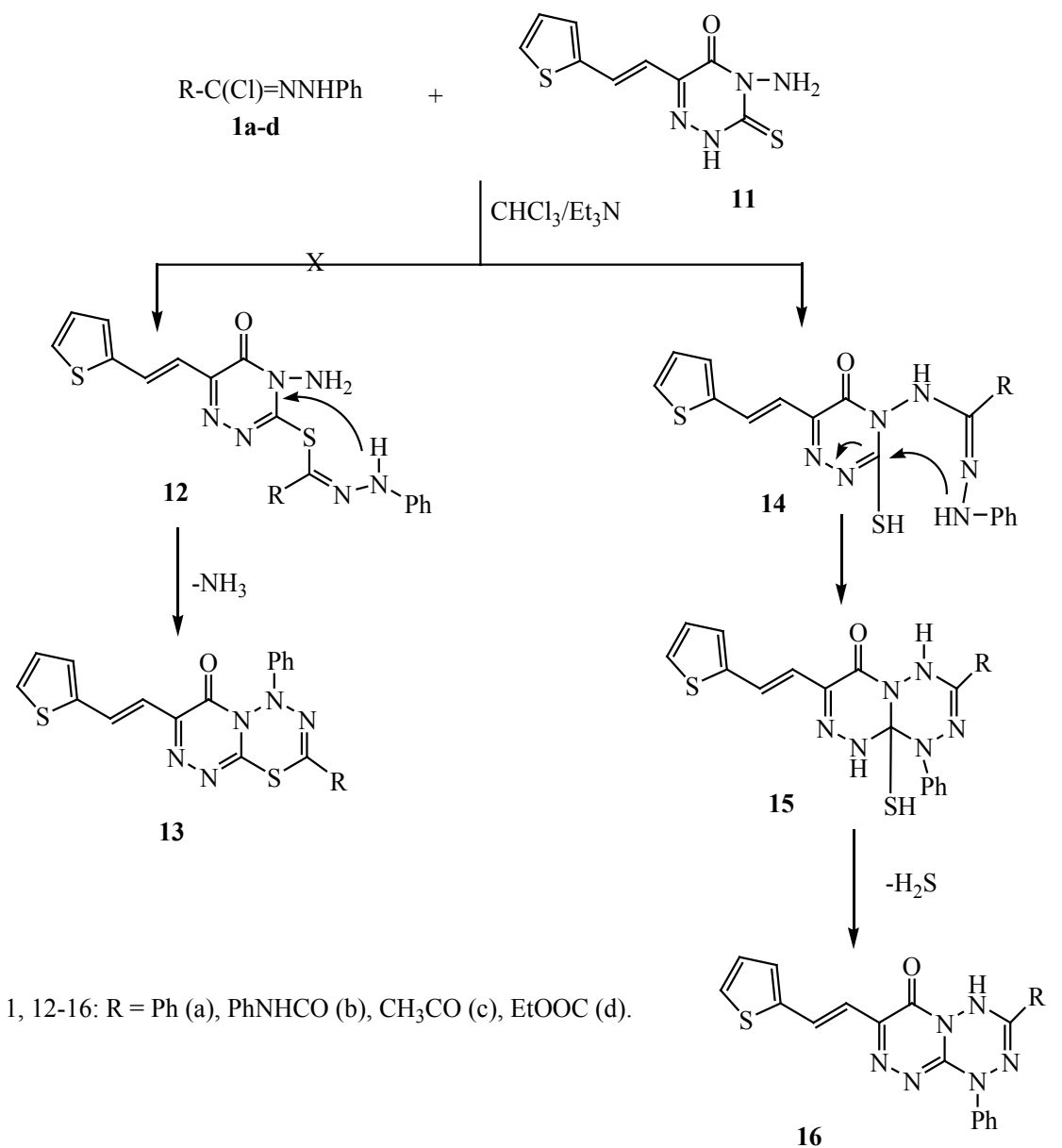

Scheme 4. Reaction of 4-amino-6-[2-(thiophen-2-yl) ethenyl]-3-thioxo-3,4-dihydro1,2,4-triazin-5(2H)-one(11) with Hydrazonoyl Chlorides 1a-d.

were identified as 1,3-disubstituted-7-[(E)-2-(thiophen-2-yl)ethenyl]-1,4,9,9atetrahydro-6 $H$-[1,2,4] triazino[4,3-b][1,2,4,5]-tetrazin-6-one (16) and not 13. The structures of the latter products were elucidated on the basis of their spectra $\left({ }^{1} \mathrm{H} \&{ }^{13} \mathrm{C}\right.$ NMR, IR, and MS) and microanalyses. For example, the ${ }^{1} \mathrm{HNMR}$ spectra of the product 16a showed NH proton signal at $\delta 8.8$, and it was lacking the $\mathrm{N}-\mathrm{NH}_{2}$ signal at $\delta 6.5$, which is characteristic of the starting substrate 11 . The mass spectra of $16 \mathrm{a}$ were also consistent with its assigned structures, especially its molecular ion peak. The formation of $16 \mathrm{a}-\mathrm{d}$ from $1 \mathrm{a}-\mathrm{d}$ and 11 can be rationalized in terms of the pathway outlined in Scheme 4. It is suggested that the reaction begins with the formation of the respective hydrazide 14, that cyclized to 15 , which in turn give 16 with concurrent elimination of hydrogen sulfide (Scheme 4) [41] [42].

\subsection{Antimicrobial Activity}

The test results revealed that all compounds exhibited moderate activity against the two bacterial species except, 5, $\mathbf{6 b}$ and all compounds showed no activity against all fungal species, except compounds 5 , and $16 \mathrm{c}$ against Candida albicans (CA) (Table 1). 
Table 1. Antibacterial and antifungal activities of some of the synthesized compounds.

\begin{tabular}{ccccc}
\hline Compound No. & $(\mathrm{EC}) \mathrm{G}^{-}$ & $(\mathrm{SA}) \mathrm{G}^{+}$ & $(\mathrm{AF})$ Fungus & (CA) Fungus \\
\hline Control: DMSO & 0.0 & 0.0 & 0.0 & 0.0 \\
Ampicillin Antibacterial agent & $22+++$ & $18+++$ & - & - \\
Amphotericin B Antifungal agent & - & - & $17++$ & $19++$ \\
4 & $11++$ & $12++$ & $0.0-$ & $0.0-$ \\
5 & $9+$ & $10++$ & $0.0-$ & $10++$ \\
$6 \mathrm{a}$ & $0.0-$ & $0.0-$ & $0.0-$ & $0.0-$ \\
$6 \mathrm{~b}$ & $0.0-$ & $0.0-$ & $0.0-$ & $0.0-$ \\
$16 \mathrm{a}$ & $9+$ & $9+$ & $0.0-$ & $0.0-$ \\
$16 \mathrm{~b}$ & $17++$ & $20+++$ & $0.0-$ & $0.0-$ \\
$16 \mathrm{c}$ & $11++$ & $11++$ & $0.0-$ & $11++$ \\
$16 \mathrm{~d}$ & $15++$ & $14+++$ & $0.0-$ & $0.0-$ \\
\hline
\end{tabular}

${ }^{*} \mathrm{IZD}=2-10 \mathrm{~mm}$ beyond control $=+$ (low activity). IZD $=11-24 \mathrm{~mm}$ beyond control $=++$ (moderate ac tivity). IZD $=25-35 \mathrm{~mm}$ beyond control = +++ (high activity).

\section{Conclusion}

In this report, it is found that hydrazonoyl chlorides (1) are good precursor to synthesize fused heterocycles. Thus the reaction of such hydrazonoyl chlorides (1) with 1,3,6-triphenyl-9-thioxo-9,10-dihydropyrimido[4,5-b]pyrido[4,5- $d][1,2,4]$ triazol o[4,3-a]pyrimidin-5,7(1H,8H)-dione (5) and 4-amino-6-[(2-thiophen-2-yl) ethenyl]-3-thioxo-3,4-dihydro-[1,2,4]triazin-5(2H)-one (11) afforded to new functionalized fused heterocycles. Spectral data revealed that such fused heterocycles have the structures of 1,3,6,9,11-penta-substitutedpyrido[3,2- $f$ 6,5-5- $f$ ] bis([1,2,4] triazolo[4,3-a]-pyrimidin-5(1H)-ones (6) and 1,3-disubstituted-7-[(E)-2(thiophen-2-yl)ethenyl]-1,4,9,9a-tetrahydro-6H-[1,2,4]triazino[4,3-b][1,2,4,5]tetrazin-6-ones (16) respectively. The antibacterial and antifungal activity screening of the prepared compounds revealed moderate activity against the bacterial species.

\section{Acknowledgements}

The authors thank King Abdulaziz City for Science and Technology (KACST), Kingdom of Saudi Arabia (KSA) for the financial support under project number AT36-062. This paper is dedicated to the memory of Prof. Dr. Dr. Ahmad Sami Abdelshakour Shawali, Cairo University, Egypt.

\section{References}

[1] Huisgen, R. (1963) 1,3-Dipolar Cycloadditions: FMO and Beyond. Angewandte Chemie International Edition, 2, 633-565. https://doi.org/10.1002/anie.196306331

[2] Phillips, R.R. and Adams, R. (1959) Organic Reactions. Vol. 1, John Wiley, New 
York, 4-143.

[3] Shawali, A.S. and Mosselhi, M.A.N. (2005) The Chemistry of Thiohydrazonates and Their Utility in Organic Synthesis. Journal of Sulfur Chemistry, 26, 267-303. https://doi.org/10.1080/17415990500124586

[4] Saleh, T.S., Narasimharao, K., Ahmed, N.S., Basahel, S.N., Al-Thabaiti, S.A. and Mokhtar, M. (2013) Mg-Al Hydrotalcite as an Efficient Catalyst for Microwave Assisted Regioselective 1,3-Dipolar Cycloaddition of Nitrilimines with the Enaminone Derivatives: A Green Protocol. Journal of Molecular Catalysis A: Chemical, 367, 1222. https://doi.org/10.1016/j.molcata.2012.11.009

[5] Gobouri, A.A.H., Mohamed, M.A.M. and Amin, M.A. (2016) Tandem Reactions Using Nitrile Imines: Synthesis of Some Novel Heterocyclic Compounds with Expected Biological Activity. Oriental Journal of Chemistry, 32, 149-158. https://doi.org/10.13005/ojc/320115

[6] Zaki1, Y.H., Sayed, A.R. and Elroby, S.A. (2016) Regioselectivity of 1,3-Dipolar Cycloadditions and Antimicrobial Activity of Isoxazoline, Pyrrolo[3,4- $d$ ] Isoxazole4,6-Diones, Pyrazolo[3,4- $d$ Pyridazines and Pyrazolo[1,5-a]Pyrimidines. Chemistry Central Journal, 10, 1-13.

[7] Farghaly, T.A., Gomha, S.M., Sayed, A.R. and Khedr, M.A. (2016) Hydrazonoyl Halides as Precursors for Synthesis of Bioactive Thiazole and Thiadiazole Derivatives: Synthesis, Molecular Docking and Pharmacological Study. Current Organic Synthesis, 13, 445-455. https://doi.org/10.2174/1570179412666150817220018

[8] Abdalla, M., Gomha, S., Abdelaziz, M. and Seragi, N. (2016) Synthesis and Evaluation of Some Novel Thiazoles and 1,3-Thiazines as Potent Agents against the Rabies Virus. Turkish Journal of Chemistry, 40, 441-453.

https://doi.org/10.3906/kim-1506-13

[9] Shawali, A.S., Farghaly, T.A. and Nawar, T.M.S. (2016) Chemoselectivity in Reactions of Hydrazonoyl Halides with Ethyl 2(3H)-Permidinylideneacetate. Journal of Heterocyclic Chemistry, 53, 909. https://doi.org/10.1002/jhet.2151

[10] Šeršeňl, F., Gregáň, F., Peško, M., Dvoranová, D., Královál, K., Matkovičovál, Z., Gregáň, J. and Donovalová, J. (2016) Synthesis and Herbicidal Activity of New Hydrazide and Hydrazonoyl Derivatives. Molecules, 20, 14139-14154.

[11] Shawali, A.S. and Parkanyi, C. (1980) Hydrazidoyl Halides in the Synthesis of Heterocycles. Journal of Heterocyclic Chemistry, 17, 833-854. https://doi.org/10.1002/jhet.5570170501

[12] Shawali, A.S. (1983) Reactions of Hydrazidoyl Halides with Sulfur Compounds. Heterocycles, 20, 2239-2285. https://doi.org/10.3987/R-1983-11-2239

[13] Shawali, A.S. (1993) Reactions of Heterocyclic Compounds with Nitrilimines and Their Precursors. Chemical Reviews, 93, 2731-2777. https://doi.org/10.1021/cr00024a007

[14] Shawali, A.S. and Abdallah, M.A. (1995) The Chemistry of Heterocyclic Hydrazonoyl Halides. Advances in Heterocyclic Chemistry, 63, 277-338. https://doi.org/10.1016/S0065-2725(08)60474-2

[15] Shawali, A.S. and Elsheikh, S.M. (2001) Annelated[1,2,4,5]Tetrazines. Journal of Heterocyclic Chemistry, 38, 541-559. https://doi.org/10.1002/jhet.5570380301

[16] Shawali, A.S. and Mosselhi, M.A.N. (2003) Hydrazonoyl Halides: Useful Building Blocks for the Synthesis of Arylazoheterocycles. Journal of Heterocyclic Chemistry, 40, 725-746. https://doi.org/10.1002/jhet.5570400428

[17] Shawali, A.S. and Sherif, S.M. (2007) The Chemistry of Hydrazonates. Current Organic Chemistry, 11, 773-799. https://doi.org/10.2174/138527207780831747 
[18] Shawali, A.S. and Edrees, M.M. (2006) Reactions of Nitrilimines with Heterocyclic Amines and Enamines. Convenient Methodology for Synthesis and Annulation of Heterocycles. Arkivoc, 2006, 292-365.

[19] Shawali, A.S. and Gomha, S.M. (2002) Regioselectivity in 1,5-Electrocyclization of $\mathrm{N}$-[as-triazin-3-yl]nitrilimines. Synthesis of $s$-Triazolo[4,3-b]-as-triazin-7(8H)-ones. Tetrahedron, 58, 8559-8564. https://doi.org/10.1016/S0040-4020(02)00946-8

[20] Shawali, A.S., Abdallah, M.A., Mosselhi M.A.N. and Elewa, M.S. (2007) A New SiteSelective Routes for Synthesis of Functionalized Imidazo[2,1-c][1,2,4]triazoles. Journal of Heterocyclic Chemistry, 44, 285-288. https://doi.org/10.1002/jhet.5570440202

[21] Mosselhi, M.A.N. (2002) A Convenient Synthesis of Novel Derivatives of Pyrido[2,3-d] [1,2,4] triazolo[4,3-a]pyrimidin-5,6-dione. Monatshefte für Chemiel Chemical Monthly, 133, 1297-1304. https://doi.org/10.1007/s00706-002-0469-8

[22] Mosselhi, M.A.N., Abdallah, M.A., Farghaly, T.A. and Shawali, A.S. (2004) Novel Pentaheterocycles. First General Synthetic Entry to Functionalized Derivatives of Pyrido[2,3-f:6,5-f] di[1,2,4]triazolo[4,3-a] Pyrimidin-5(1H)-ones. Monatshefte für Chemiel Chemical Monthly, 135, 211-222.

https://doi.org/10.1007/s00706-003-0113-2

[23] Turan-Zitounim, G., Kaplancikli, Z.A., Yildiz, M.T., Chevallet, P. and Kaya, D. (2005) Synthesis and Antimicrobial Activity of 4-Phenyl/cyclohexyl-5-(1-phenoxyethyl)-3-[ $N$-(2-thiazolyl)acetamido]thio-4H-1,2,4-triazole derivatives. European Journal of Medicinal Chemistry, 40, 607-613. https://doi.org/10.1016/j.ejmech.2005.01.007

[24] Holla, B.S., Mahalinga, M., Karthikeyan, M.S., Akberali, P.M. and Shetty, N.S. (2006) Synthesis of Some Novel Pyrazolo[3,4- $d$ ]pyrimidine Derivatives as Potential Antimicrobial Agents. Bioorganic \& Medicinal Chemistry, 14, 2040-2047. https://doi.org/10.1016/j.bmc.2005.10.053

[25] El-Bendary, E.R. and Badria, F.A. (2000) Synthesis, DNA-Binding, and Antiviral Activity of Certain Pyrazolo[3,4-d]pyrimidine Derivatives. Archiv der Pharmazie, 333, 99-103. https://doi.org/10.1002/(SICI)1521-4184(20004)333:4<99::AID-ARDP99>3.0.CO;2$\underline{\mathrm{O}}$

[26] Liu, H., Wang, H.Q. and Liu, Z. (2007) Synthesis and Herbicidal Activity of Novel Pyrazolo[3,4- $d$ ]pyrimidin-4-one Derivatives Containing Aryloxyphenoxypropionate Moieties. Bioorganic \& Medicinal Chemistry Letters, 17, 2203-2209.

https://doi.org/10.1016/j.bmcl.2007.01.083

[27] Lavecchia, G., Berteina-Robin, S. and Guillaumet, G. (2005) Selective Bifunctionalization of Pyrido[2,3-d]pyrimidines in Positions 2 and 4 by $\mathrm{SN}_{\mathrm{Ar}}$ and PalladiumCatalyzed Coupling Reactions. Tetrahedron Letters, 46, 5851-5855. https://doi.org/10.1016/j.tetlet.2005.06.141

[28] Hassaneen, H.M., Farag, A., Shawali, A.S. and Algharib, M.S. (1987) Regioselectivity in Dipolar Cycloaddition Reactions of N-Phenylcinnamonitrilimine. Journal of Heterocyclic Chemistry, 24, 577-580. https://doi.org/10.1002/jhet.5570240308

[29] Fitton, A.O. and Smalley, R.K. (1968) Practical Heterocyclic Chemistry. Academic press, London and New York, 26.

[30] Hodgkinson, A.J. and Staskan, B. (1969) Conversion of 2,2-Dichloroacetoacetanilides into 4-Hydroxymethyl-2(1H)-quinolones. The Journal of Organic Chemistry, 34, 1709-1713. https://doi.org/10.1021/jo01258a039

[31] Tapp, F.R. and Klingemann, F. (1887) Japp-Klingemann Reaction. Chemische Berichte, 20, 2942-2944. 
[32] Taylor, E.C. and Cheng, C.C. (1960) Notes-Purine Chemistry. VII. An Improved Synthesis of Hypoxanthine. The Journal of Organic Chemistry, 25, 148-149. https://doi.org/10.1021/jo01071a611

[33] Abdallah, T.A., Darwish, M.A. and Hassaneen, H.M. (2002) A Novel Synthesis of 1,2,4-Triazolopteridines. Molecules, 7, 494-500. https://doi.org/10.3390/70600494

[34] Pfaller, M.A., Burmeister, L., Bartlett, M.A. and Rinaldi, M.G. (1988) Multicenter Evaluation of Four Methods of Yeast Inoulum Preparation. Journal of Clinical Microbiology, 26, 1437-1441.

[35] Matar, M.J., Ostrosky-Zeichner, L., Paetznick, V.L., Rodriguez, J.R., Chen, E. and Rex, J.H. (2003) Correlation between E-Test, Disk Diffusion and Microdilution Methods for Antifungal Susceptibility Testing of Fluconazole and Voriconazole. Antimicrobial Agents and Chemotherapy, 47, 1647-1651. https://doi.org/10.1128/AAC.47.5.1647-1651.2003

[36] Reiter, J., Bongo, L. and Dyortsok, P. (1987) On triazoles XI. Structure Elucidation of Isomeric 1,2,4-Triazolopyrimidinones. Tetrahedron, 43, 2497-2504. https://doi.org/10.1016/S0040-4020(01)81656-2

[37] Geis, A.A., Kamal-Eldeen, A.M., Abdelhafez, A.A. and Gaber, A.M. (1991) Synthesis of Some Thiazolo-[3,2-a]pyrimidines. Phosphorus, Sulfur, and Silicon and the Related Elements, 56, 87-93. https://doi.org/10.1080/10426509108038070

[38] Elliott, A.J., Callaghan, P.D., Gibson, M.S. and Nemeth, S.T. (1975) The Rearrangement of Aryl Thiohydrazonates. Canadian Journal of Chemistry, 53, 14841490. https://doi.org/10.1139/v75-206

[39] Youssif, S., El-Bahaie, S. and Nabih, E. (1999) A Facile One-Pot Synthesis of Pyrido[2,3-d]pyrimidines and Pyrido[2,3-d:6,5- $d$ ] dipyrimidines. Journal of Chemical Research, Synopses, 112-113. https://doi.org/10.1039/a806513f

[40] Mosselhi, M.A.N., Saad, H.A. and Youssef, M.M. (2011) Microwave Assisted Synthesis of Some New Fused 1,2,4-Triazines Bearing Thiophene Moieties with Expected Pharmacological Activity. Molecules, 16, 4937-4957.

https://doi.org/10.3390/molecules 16064937

[41] Shawali, A.S., Elghandour, A.A. and El-Sheikh, S.M. (2000) A One-Pot Synthesis of $[1,2,4]$ Triazino[4,3-b]-[1,2,4,5]tetrazines. Advanced Synthesis \& Catalysis, 342, 9699.

https://doi.org/10.1002/(SICI)1521-3897(200001)342:1<96::AID-PRAC96>3.0.CO;2 $\underline{-M}$

[42] Shawali, A.S., Elghandour, A.A. and El-Sheikh, S.M. (2000) A New One-Step Synthesis of Pyrimido[1,2-b][1,2,4,5]tetrazines. Heteroatom Chemistry, 11, 87-90.

[43] Saad, H.A., Aly, M.R.E. and Abdel-Hafez, S.H. (2015) Three-Component Process for the Synthesis of Pyrimido[2,1-c][1,2,4]triazine Derivatives via Knoevenagel Condensation under Thermal Aqueous Conditions. Current Organic Synthesis, 12, 208-219. https://doi.org/10.2174/1570179412666141212193009 
Submit or recommend next manuscript to SCIRP and we will provide best service for you:

Accepting pre-submission inquiries through Email, Facebook, LinkedIn, Twitter, etc. A wide selection of journals (inclusive of 9 subjects, more than 200 journals)

Providing 24-hour high-quality service

User-friendly online submission system

Fair and swift peer-review system

Efficient typesetting and proofreading procedure

Display of the result of downloads and visits, as well as the number of cited articles Maximum dissemination of your research work

Submit your manuscript at: http://papersubmission.scirp.org/

Or contact ijoc@scirp.org 